\title{
OYSTER CONDITION INDEX IN Crassostrea rhizophorae (GUILDING, 1828) FROM A HEAVY-METAL POLLUTED COASTAL LAGOON
}

\author{
REBELO, M. F., AMARAL, M. C. R. and PFEIFFER, W. C. \\ Laboratório Radioisótopos Eduardo Penna-Franca, Instituto de Biofísica Carlos Chagas Filho, CCS, Bl. G, \\ Universidade Federal do Rio de Janeiro, Cidade Universitária, Rio de Janeiro, RJ, Brazil \\ Correspondence to: M. F. Rebelo, Laboratório Radioisótopos Eduardo Penna-Franca, Instituto de Biofísica Carlos \\ Chagas Filho, CCS, Bl. G, Universidade Federal do Rio de Janeiro, Cidade Universitária, Rio de Janeiro, RJ, Brazil, \\ CEP 21941-900, e-mail: mrebelo@ biof.ufrj.br \\ Received May 14, 2003 - Accepted October 13, 2003 - Distributed May 31, 2005
}

(With 2 figures)

\begin{abstract}
The condition index (CI) of oysters represents an ecophysiological approach to estimate meat quality and yield in cultured bivalve mollusks. In the present study, the CI of oysters from a heavy-metal polluted bay was analyzed with respect to $\mathrm{Zn}$ and $\mathrm{Cd}$ contamination in soft tissues, spawning, and polychaete infestation. The CI was calculated through a new technique based on molds made to measure the volume of oyster-shell internal cavities. The higher CI values (over 9 in the dry season) were probably related availability of suspended particles rich in organic matter in the bay, while the rapid reduction in the CI from one season to the next at some stations suggests the effect of spawning. Polychaete infestation was considered low $(18.7 \%)$ and produced no clear CI effects. The Cd in the oyster tissue collected during the rainy season was weak, although still significantly correlated with the CI $(\mathrm{r}=$ -0.36; $\mathrm{p}<0.05$ ). All other comparisons of CI and metal concentrations demonstrated a non-significant correlation. The CI variations observed on the temporal and spatial scale were likely to have been caused by availability of organic matter and spawning, rather than spionid infestation or metal body burdens.
\end{abstract}

Key words: condition index, oysters, heavy metal, polychaete, Sepetiba Bay, Brazil.

\section{RESUMO}

Índice de condição de ostras Crassostrea rhizophorae (Guilding 1828) de uma baía contaminada por metais pesados

O índice de condição (IC) de ostras é um índice ecofisiológico utilizado para avaliar a qualidade e a produtividade em cultivos de bivalves. No presente estudo, o IC de ostras de uma baía contaminada por metais pesados foi analisado em relação ao conteúdo de $\mathrm{Zn}$ e $\mathrm{Cd}$ nos tecidos moles, à liberação de gametas após o período reprodutivo e à infestação por poliquetas. O IC foi calculado com uma nova técnica que utiliza moldes da cavidade interna da concha para medir seu volume. Os maiores valores de IC (acima de 9 na estação seca) podem estar relacionados à disponibilidade de material particulado em suspensão rico em matéria orgânica na baía, enquanto a rápida redução do IC observada de uma temporada a outra em algumas estações é um provável efeito da liberação de gametas. A infestação por poliquetas foi considerada baixa $(18,7 \%)$ e não apresenta efeitos claros no IC. Apenas Cd nos tecidos de ostras coletadas durante a estação das chuvas apresentou correlação baixa, porém significativa $(\mathrm{r}=-0,36 ; \mathrm{p}<0,05)$, com o IC. Todas as outras correlações entre metais e IC foram estatisticamente não significativas. As variações do IC observadas em escala espacial e temporal parecem ser causadas mais pela disponibilidade de material particulado rico em material orgânico e pela liberação de gametas do que pela infestação por poliquetas e acúmulo de metais nos tecidos.

Palavras-chave: índice de condição, ostra, metal pesado, poliquetas, baía de Sepetiba, Brasil. 


\section{INTRODUCTION}

Oysters are widely used for environmental monitoring purposes. Some physiological factors such as spawning and growth can directly affect their ability to indicate pollution or environmental contamination. At the same time, pollutants can affect these physiological factors, thus the importance of better understanding the dynamics of these physiological processes.

The condition index $(\mathrm{CI})$ is used to estimate meat quality and yield in cultured bivalve mollusks. Despite some variations, the index is calculated with the formula in Galtsoff (1964), i.e., the ratio of the dry meat weight to the shell's internal cavity volume. This yields the extent to which an oyster's potential growth has been reached.

As an ecophysiological index, the CI can be affected by multiple abiotic factors and physiological activities, among which spawning is one of the most important. While seasonally regulated in temperate climates, this is apparently not so in the tropics. For the mangrove oyster Crassostrea rhizophorae, gametogenesis is a continuous process, homogeneous within the population, with spawning occurring in partial discharges during the entire year, with peaks every 3 months (Ramos \& Nascimento, 1980).

Among the factors negatively influencing the $\mathrm{CI}$ is infestation by the worm Polydora sp., since oysters have to mobilize energy to produce the blisters in which the pest is contained (Handley, 1998). This leads some authors to regard CI as a nonspecific index of pollution (Ruddy et al., 1975; Scott \& Lawrence, 1982; Lawrence \& Scott, 1982) and others to normalize contaminant concentrations in soft tissues so as to standardize the influence of the physiological state in pollutant bioaccumulation (Riedel et al., 1998; Caceres-Martinez et al., 1998; Joiris et al., 2000).

Sepetiba Bay $\left(23^{\circ} \mathrm{S} ; 44^{\circ} \mathrm{W}\right)$ is a semi-enclosed coastal lagoon, with high sedimentation rates and long water-residence times. It is highly polluted with heavy metals, especially $\mathrm{Zn}$ and $\mathrm{Cd}$, principally originating from improper disposal of wastewater from a smelting plant over the past 40 years (Barcellos et al., 1991). Besides this point source of pollution, there is a drainage basin with three main rivers that contribute not only other pollutants, but also, and especially, nutrients from urban areas. Recently, dredging entailed by the construction of the Sepetiba super harbor have re-suspended contaminated sediments, which had been disposed of in a central area inside the bay, making it necessary to reevaluate oyster contamination levels. Metal contamination in sediments and oyster tissues been evaluated by several authors (Pfeiffer et al., 1985; Lima et al., 1986; Lacerda et al., 1987). In a recent study, oysters exhibited extremely high $\mathrm{Zn}$ and $\mathrm{Cd}$ concentrations (Rebelo et al., 2003), and raised the question of how this many have affected oyster development.

In contrast to more commonly used exposure bioindicators, e.g., metal bioaccumulation in tissue, the condition index is not related to a specific contaminant and could work as an effect bioindicator to show how populations are being affected.

In the present study, seasonal and spatial trends of the CI were related to metal body burdens and infestation by the worm Polydora sp.

\section{MATERIAL AND METHODS}

An average of 30 to 40 oysters were collected on the rocky shores (supra-tidal level) at 10 stations in Sepetiba Bay (8 contaminated sites inside the bay and 2 outside controls) in 5 different surveys during one year. The sampling area and control stations are detailed in Fig. 1. Samples were grouped in pools of 3-6 individuals each (shell length $4.8 \pm$ $0.9 \mathrm{~cm}$ ) and surveyed during the dry (May-August 1998 and July 1999) and rainy (November 1998 and March 1999) seasons.

Oysters were shucked and the soft tissue was wet and dry weighed $\left(80^{\circ} \mathrm{C}\right.$ for 48 hours $)$. Internal cavity volume was determined with a new technique developed to allow volume calculation in previously dissected oysters. Molds of the internal cavity were made using wheat flour paste. Subsequently, the empty shells were filled with the same paste. After drying at room temperature for $30 \mathrm{~min}$, shells were removed from the mold, which was then introduced into a water-filled glass column to verify water displacement. Displaced water dripped through a tap in the column and was collected in a Petri dish over a balance. Through the water weight, volume was calculated in $\mathrm{ml}$. The condition index was then calculated as described by Scott \& Lawrence 
(1982): CI = meat dry weight $(\mathrm{g}) \times 100 /$ internal cavity volume $(\mathrm{ml})$.

Infestation by Polydora sp. was quantified by direct count of mud blisters in the oyster shells, and presented as the percentage of shells presenting mud blisters in relation to the total number of oysters sampled in each particular station and survey.

Metal concentrations in oyster soft tissue used in this study were determined through another study in our laboratory and are described in Rebelo et al. (2003). Briefly, oysters were dissected, dry weighed, ashed, digested with concentrated nitric and hydrochloric acid, and analyzed by a flame atomic absorption spectrometer (Varian 1475). Results were validated with analysis of certified reference material (NIST 296). Recovery percentages were $90 \%$ for $\mathrm{Zn}$ and $87 \%$ for $\mathrm{Cd}(\mathrm{n}=10)$.

Due to lack of normality in the data sets, nonparametric statistics were used to analyze the results. The Spearman correlation was used to verify the relation between metal concentrations and CI. The Mann-Whitney test was used to compare results among surveys and sampling stations. Differences were considered significant if $\mathrm{p}<0.05$. Analyses were performed using Statistica software (Statsoft, 2002).

\section{RESULTS}

Calculated values of the condition index (CI) for oysters from the 10 stations in Sepetiba Bay in the dry and rainy seasons are presented in Fig. 2. The Mann-Whitney test showed significantly higher values for the oyster CI in the dry season (median 7.75) than in the rainy season (median 5.09). Nevertheless, not all stations exhibited this pattern: higher CIs were observed in the rainy season at AGU, CAT, and MAB stations.

We also observed differences between CI's in different stations using the Mann-Whitney test. In the dry season CI was significantly higher $(\mathrm{p}<$ 0.05 ) for sampling stations located in the middle part of the bay (GAT median 7.73; PGD median 8.01 ) in comparison to control ones (MAB median 4.43; ANG median 4.78).

Infestation by Polydora sp. was quite low, with an average of $18.7 \%$. Despite significantly higher values during the rainy season (median $15.28 \%$; Mann-Whitney: $\mathrm{p}>0.05$ ), there seems to be a clear trend in spatial or temporal variation (Table 1). In most of the stations the percentage of infestation was higher in the rainy season. At AGU it was very similar during both seasons, while at GAT and MAB the opposite tendency was observed.

The correlation between metal concentrations and CI was very weak, with small (Spearman r) coefficient values, and significant only for $\mathrm{Cd}(\mathrm{r}=$ $-0.36 ; \mathrm{p}<0.05$ ) during the rainy season (Table 2 ).

\section{DISCUSSION}

Using the condition index in the study of oyster populations in Sepetiba Bay allowed us to make some suppositions about how environmental contamination and physiological status relate to this ecophysiological variable. A glance at Fig. 1 shows that, especially in the dry season in which CI values were higher, the CIs of oysters from stations in the central bay area (e.g., CGD maximum value 9) present higher values than do those of the external control stations (ANG minimum 4.4). For the rainy season the pattern could be the same, despite some stations (GAT, MAT) exhibiting a significant CI drop from one season to the other.

Rather than being a seasonal effect, the sudden CI drop appears to be caused by spawning, a biological event known to significantly reduce oyster biomass in a matter of days (Nascimento \& Pereira, 1980). In temperate climates, oysters start to accumulate glycogen before winter and use these reserves for gametogenesis in the forthcoming season (Handley, 1998). As stated before, in tropical environments spawning is not seasonal; however, it is still a key factor causing differences in oyster conditions over time. Nascimento \& Pereira (1980) observed a sudden CI drop caused by spawning in a 3-month study in Todos os Santos Bay (northeastern Brazil). Thus, it is probable that the same mechanism explains the smaller CI values in oysters from Sepetiba Bay during the rainy season (spring-summer).

Values observed in our study are in agreement with others previously reported in different regions of Brazil. High values in Todos os Santos Bay were 7.8 during spring and 4.39 in the summer, after spawning (Nascimento \& Pereira, 1980). Muniz et al. (1986) calculated an annual mean CI value of 11 in southeastern Brazil. 
The high values closer to the point source of pollution are in contrast to what might have expected considering the possible effects of metal contamination on oyster growth. But if we bear in mind that this area also receives the organic discharge of 3 rivers that drain an urban coastal area, the high CI values are representative of the high primary production in the region, and may suggest eutrophization processes in the bay.

Corroborating this idea, Rees et al. (1998), who also carried out work in Sepetiba Bay, showed that near the shore and in river estuaries, suspended particulate matter is high, reaching $250 \mathrm{mg} . \mathrm{L}^{-1}$, and is dominated by red-brown clay particles, whereas particulate concentrations in other stations are usually higher than $100 \mathrm{mg} . \mathrm{L}^{-1}$ (concentration ranges from 41.7 to $318 \mathrm{mg} . \mathrm{L}^{-1}$ and averages 160 $\mathrm{mg} . \mathrm{L}^{-1}$ ) and are dominated by dark green algal slime. This highly organic particulate matter represents the primary source of food for the oyster and is probably contributing to enhance the oyster CI in this area. Moreover, Muniz et al. (1986) also found an increase in $C$. gigas CI during upwelling periods. They attributed this to enhancement in primary production $\left(10 \mu \mathrm{g} \cdot \mathrm{g}^{-1}\right.$ chlorophyll).

In our work, the infestation percentage was not higher in stations previously described as heavily contaminated with $\mathrm{Zn}$ and $\mathrm{Cd}$. In addition, infestation does not seem to be related to spatial variation, as we could find both smaller and greater values in the control stations (ANG had clearly higher infestation values than did MAB) and in those in different areas of the bay. Stations MAT and CGD, which are close respectively to GAT and $\mathrm{PGD}$, and also similar in sediment type (coarse in MAT and GAT; mud in CGD and PGD), exhibited higher infestation values.

The significantly higher infestation by the pest in the rainy season could be a result of lower physiological resistance, which subsequently contributed to lower CI values. Nevertheless, comparing the $\mathrm{CI}$ and the percentage of infestation during the dry and rainy seasons, many behaviors appear for both variables, none of which can be used in determining a pattern. Overall, infestation by Polydora sp. in Sepetiba Bay seems to be low, which may account for finding no clear influence on the $\mathrm{CI}$ values. Average values for oysters containing shell blisters are low in Sepetiba Bay (18.7\%) when compared to those found by Handley (1997) in Marlborough Sounds, New Zealand (57\%).

High infestation recorded for the ANG control station (low metal values), as well as low for the GAT (high Zn and Cd concentrations) shows that Spionid infestation is not related to metal contamination. In this particular, these results differ from those of Almeida et al. (1996) who found that zinc, iron, and manganese concentrations were significantly higher in infested shells.

TABLE 1

Percentage of infestation in oysters from each sampling station in rainy and dry season. See Fig. 1 for legend for sampling stations.

\begin{tabular}{|c|c|c|}
\hline Site & Rainy & Dry \\
\hline MAD & 31.6 & 7.3 \\
\hline GAT & 0.0 & 6.4 \\
\hline MAT & 25.4 & 4.5 \\
\hline CGD & 24.0 & 8.6 \\
\hline PGD & 6.3 & 0.0 \\
\hline AGU & 13.3 & 11.1 \\
\hline CAT & 27.3 & 1.6 \\
\hline 2IR & 2.3 & 0.0 \\
\hline MAB & 0.0 & 4.9 \\
\hline ANG & 17.9 & 5.1 \\
\hline
\end{tabular}




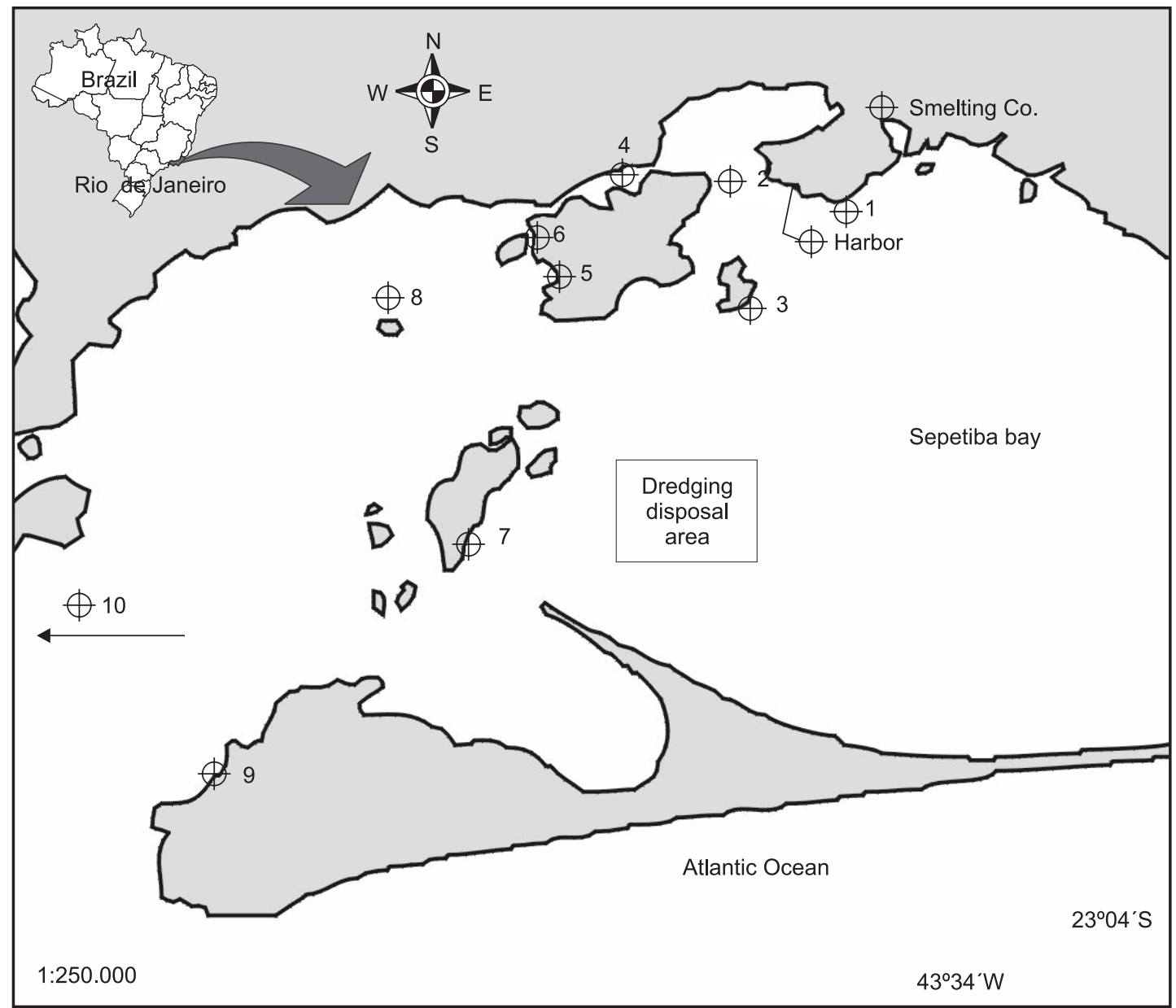

Fig. 1 - Study area and sampling station. 1. Madeira Island (MAD); 2. Gato Island (GAT); 3. Martins Island (MAT); 4. Coroa Grande inlet (CGD); 5. Praia Grande Beach (PGD); 6. Aguada Beach (AGU); 7. Catita Beach (CAT); 8. Duas Irmãs Island (2IR); 9. Marambaia Island (MAB); and 10. Saco de Piraquara de Dentro - Angra dos Reis (ANG). MAB and ANG are control stations.

TABLE 2

Spearman correlation coefficient between heavy metal $\mathrm{Zn}$ and $\mathrm{Cd}$ in the tissue of oysters and the condition index of the organisms. Significant coefficients marked with asterisks.

\begin{tabular}{|c|c|c|}
\hline Site & Rainy & Dry \\
\hline $\mathrm{Zn}$ & 0.2 & -0.13 \\
\hline $\mathrm{Cd}$ & 0.11 & $-0.36^{*}$ \\
\hline
\end{tabular}




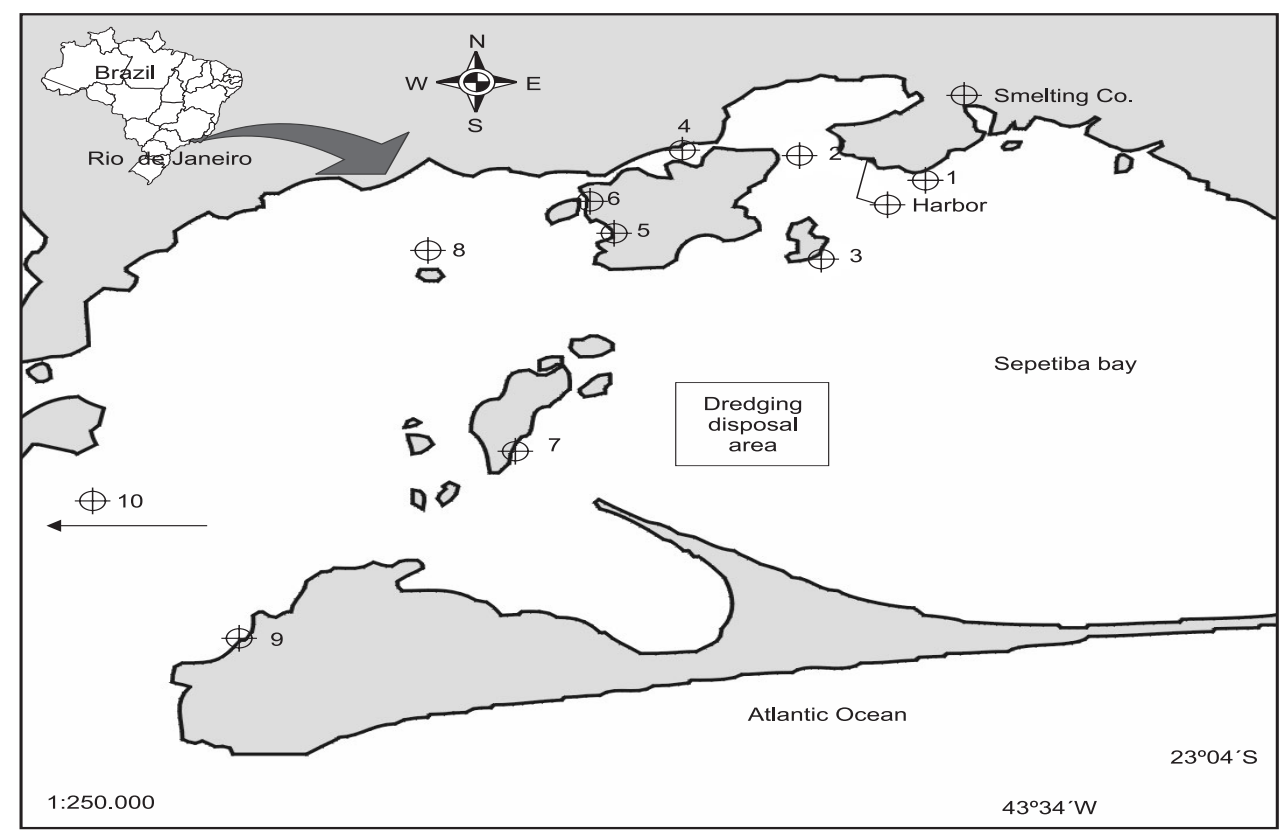

Fig. 2 - Condition index median values of 5-8 sample pools in the sampled stations for rainy (dark gray symbols) and dry (light gray symbols) seasons. Bars stand for lower and higher limits; boxes 25\%-75\% quartiles; closed dots, extreme values; and asterisks, extremely high values.

We found that CI is not significantly affected by high heavy metal contamination in oyster tissue. Only Cd exhibited significant correlation with $\mathrm{CI}$, and this was so only during the spring-summer rainy season $(r=-0.36)$. The low $r$ coefficient indicates that even in this situation the contribution of one variable to the other is very small. It is also worth noting that CI has little influence in metal uptake or release. In addition, the metal accumulated in the oyster soft tissue has little toxic effect on overall metabolism.

Many authors have shown that $\mathrm{CI}$ is affected by environmental contaminants and stressors, such as metals and heat. A negative correlation, where the high metal concentration is coupled with low CI values, would represent a toxic effect of the contaminant. In studying Crassostrea virginica in a river contaminated by discharge of heavy metals (Cu, Ag, and Cd), Riedel et al. (1998) found a weak, but highly significant negative correlation between trace metals in tissues and CI.

A positive correlation could be expected in a case in which ingestion of particles rich in organic matter (and also metal adsorption) were contributing to an increase in both CI and accumulated metal. Ruddy et al. (1975) found that $C$. virginica had a clear increase in the CI when raised under the influence of hot wastewater from a power plant. But our results do not agree with those found by Scott \& Lawrence (1982), in which organic pollution, as indicated by fecal coliforms, correlated with lower CI values for $C$. virginica from a polluted site.

Paez-Osuna et al. (1995) also found no relation between metal concentration and CI. In studying the relationships between 9 metal concentrations (including $\mathrm{Cd}$ and $\mathrm{Zn}$ ) and gonadal index variation, they found that for most metals, gonadal growth does not affect metal concentration in whole body. Therefore, the attempt to normalize metal concentrations by the physiological condition of the individuals, by dividing metal concentrations by the $\mathrm{CI}$, can even introduce variability in metal determination because distinguishing between the possible mechanisms of toxicity, biological dilution, and bioconcentration acting in the organism would then be impossible. 


\section{CONCLUSIONS}

The higher condition index values that we observed in oysters from Sepetiba Bay are likely to be the result of organic-matter availability. The rapid CI decrease from one season to the other in some stations could be primarily related to spawning. Polydora sp. infestation seems to be too low to clearly influence CI. Finally, the lack of correlation between CI and metal body burdens suggests that the physiological status represented by this index does not interfere with $\mathrm{Zn}$ and $\mathrm{Cd}$ uptake or release. Furthermore, it can also indicate that the accumulation of these metals in itself does not affect the ecophysiological index.

Acknowledgements - The authors are indebted to Dr. Olaf Malm and Dr. Jean Remy Guimarães for their contributions during the revision of this manuscript, Dr. Paulo Paiva (Lab. Polychaetes, Dept. of Zoology, Rio de Janeiro Federal University) for identification of Polydora sp. in the oysters, as well as Dr. Cristine Barreto for her contribution in shell volume determination.

\section{REFERENCES}

ALMEIDA, M. J., MOURA, G., MACHADO, J., COIMBRA, J., VILARINHO, L., RIBEIRO, C. \& SOARESDASILVA, P., 1996, P Amino acid and metal content of Crassostrea gigas shell infested by Polydora sp. in the prismatic layer insoluble matrix and blister membrane. Aquat. Living Resour., 9: 179186.

BARCELlOS, C., REZENDE, C. E. \& PFEIFFER, W. C., 1991, $\mathrm{Zn}$ and $\mathrm{Cd}$ production and pollution in a brazilian coastal region. Mar. Poll. Bull., 22: 558-561.

CACERES-MARTINEZ, J., DE OCA, P. M. M. \& VASQUEZYEOMANS, R., 1998, Polydora sp. infestation and health of the pacific oyster Crassostrea gigas cultured in Baja California, New Mexico. J. Shellfish Res., 17: 259-264.

GALTSOFF, P. S., 1964, The American oyster Crassostrea virginica Gmelin. Fish. Bull., 64: 1-480.

HANDLEY, S. J., 1997, Optimizing subtidal oyster production, Marlborough Sounds, New Zealand: spionid polychaete infestations, water depth, and spat stunting. J. Shellfish Res., 16: $143-150$

HANDLEY, S. J., 1998, Power to the oyster: do spionid-induced shell blisters affect condition in subtidal oysters? J. Shellfish Res., 17: 1093-1099.

JOIRIS, C. R., HOLSBEEK, L. \& OTCHERE, F. A., 2000, Mercury in the bivalves Crassostrea tulipa and Perna perna from Ghana. Mar. Poll. Bull., 40: 457-460.
LACERDA, L. D., PFEIFFER, W. C. \& FISZMAN, M., 1987, Heavy metal distribution, fate and availability in Sepetiba Bay, se. Brazil. Sci. Total Environ., 65: 163-173.

LAWRENCE, D. R. \& SCOTT, G. I., 1982, The determination and use of condition index of oysters. Estuaries, 5: 23-27.

LIMA, N. R. W., LACERDA, L. D., PFEIFFER, W. C. \& FISZMAN, M., 1986, Temporal and spatial variability in Zn, $\mathrm{Cr}, \mathrm{Cd}$ and $\mathrm{Fe}$ concentrations in oyster tissues. (Crassostrea brasiliana, lamarck 1819) from Sepetiba Bay, Brazil. Environ. Technol. Letters, 7: 453-460.

MUNIZ, E. C., JACOB, S. A. \& HELM, M. M., 1986, Condition index, meat yield and biochemical composition of Crassostrea brasiliana and Crassostrea gigas grown in Cabo Frio, Brazil. Aqualculture, 59: 235-250.

NASCIMENTO, I. A. \& PEREIRA, A. S., 1980, Changes in the condition index for mangrove oysters (Crassostrea rhizophorae) from Todos os Santos Bay, Salvador, Brazil. Aqualculture, 20: 9-15.

PAEZ-OSUNA, F., FRIAS-ESPERICUETA, M. G. \& OSUNALOPES, J. I., 1995, Trace metal concentration in relation to season and gonadal maturation in the oyster Crassostrea iridescens. Mar. Environ. Res., 40: 19-31.

PFEIFFER, W. C., LACERDA, L. D., FISZMAN, M. \& LIMA, N. R. W., 1985, Metais pesados no pescado da baía de Sepetiba, Estado do Rio de Janeiro. Ciência e Cultura, 37: 197-302.

RAMOS, M. I. S. \& NASCIMENTO, I. A., 1980, Variações do índice gonadal na ostra de mangue Crassostrea rhizophorae guilding, 1928. Ciência e Cultura, 32: 1673-1676.

REBELO, M. F., AMARAL, M. C. R. \& PFEIFFER, W. C., 2003, High $\mathrm{Zn}$ and $\mathrm{Cd}$ accumulation in the oyster Crassostrea rhizophorae, and its relevance as a sentinel species. Mar. Poll. Bull., 46: 1354-1358.

REES, J. G., BREWARD, N., MADDOCK, J. E. L., FERGUSON, A. J. \& WILLIAMS, T. M., 1998, Assessment of contamination by metals and selected organic compounds in coastal sediments and waters of Sepetiba Bay, Rio de Janeiro state, Brazil. Technical report wc/98/30. Overseas geology series. British Geological Survey, 98p.

RIEDEL, G. F., ABBE, G. R. \& SANDERS, J. G., 1998, Temporal and spatial variations of trace metal concentrations in oysters from the Patuxent River, Maryland. Estuaries, 21: 423-434.

RUDDY, G. M., FENG, S. Y. \& CAMPBELL, G. S., 1975, The effect of prolonged exposure to elevated temperature on the biochemical constituents, gonadal development and shell deposition of the american oyster, Crassostrea virginica. Comp. Biochem. Physiol., 51b: 157-164.

SCOTT, G. I. \& LAWRENCE, D. R., 1982, The american oyster as a coastal zone pollution monitor: a pilot study. Estuaries, 5: 40-46.

STATSOFT, INC., 2002, Electronic Statistics Textbook. Tulsa, OK: StatSoft. WEB: http://www.statsoft.com/textbook/ stathome.html. 